Article

\title{
The 'Lifeblood' of Science and Its Politics: Interrogating Epistemic Curiosity as an Educational Aim
}

\author{
Marianna Papastephanou \\ Received: 19 October 2015; Accepted: 23 December 2015; Published: 30 December 2015 \\ Academic Editor: Andrew Stables \\ Department of Education, University of Cyprus, PO Box2 0537, Nicosia 1678,Cyprus; edmari@ucy.ac.cy; \\ Tel.: +357-9932-5183
}

\begin{abstract}
Social- and virtue-epistemologies connect intellectual and moral concerns in ways significant for education and its theory. For most educationists, epistemic and ethical virtues are no longer dissociated. However, many political framings or operations of epistemic virtues and vices remain neglected in educational discourses. This article illustrates why a politicization of epistemic issues is relevant to education through reference to political performances of a curiosity typically considered educationally valuable. Curiosity bore political connotations from antiquity to late modernity whose exploration may add critical nuance to educational-philosophical conceptions of epistemic desire. This leads us to the main argument of the article, which is that such politicization helps us interrogate unqualified, uniform, and glorifying treatments of curiosity as an educational aim.
\end{abstract}

Keywords: disinterested curiosity; virtue epistemology; social epistemology; desire for knowledge; colonialism; epistemic restraint

\section{Introduction}

The main argument in this article is that, against the unqualified endorsement of curiosity as an educational aim that is dominant in our field, we must interrogate curiosity politically. This interrogation will heighten our awareness of how in some instances curiosity reflects politically undesirable framings and how an uncritical welcome of it in schools may perpetuate such framings. It will help us see why a more cautious and nuanced reception of curiosity in education is needed, one that considers the possibility of epistemic restraint being in some cases politically more helpful than epistemic curiosity. Politically sensitive epistemic restraint allows the kind of pause for thought that prepares us to ask different, more critical and ethico-politically pertinent questions than before.

The steps that this complex argument requires in order to take off are the following: first comes a preparatory stage of preliminary remarks that situate the main argument by placing it into a broader educational-philosophical context of tendencies that frame the educational reception of curiosity. From then on, a head-on discussion of curiosity in education follows. The adjective "disinterested," which has been attributed to curiosity and qualified its employment in educational philosophy at a given time, operated in political ways that disentangled epistemic from moral and political stakes and prepared the ground for what ended up to be an unqualified educational welcome of curiosity. However, attention is drawn to the fact that, though social and virtue epistemologies complicate disinterestedness and reclaim the social and virtue dimensions of episteme, they fail to adequately reclaim its political operations. Likewise, a politicization of curiosity and a concomitant political queering of curiosity as an educational aim are still missing. Transfers of virtue epistemology into educational philosophy continue to treat curiosity apolitically and to recommend it unreservedly as 
an educational aim. Gleanings from curiosity's conceptual history will reveal politicizations of it that make us more sensitive to diverse (i.e., positive and negative) operations of curiosity and thus to a qualified and cautious treatment of it along with epistemic restraint as educational aims.

\section{Preliminary Remarks}

Some philosophical-educational tendencies that frame the pursuit of knowledge and our visions of goodness revolve around epistemology and ethics, and may be unpacked as follows. We define the desire for knowledge as natural and our scientific inquiries as disinterested. Yet, we are also concerned about the moral impact of our life choices, epistemic adventures, scientific findings, and goal-setting. We then organize education to align with our epistemological and moral aims.

However, even when we acknowledge the importance of asking questions about both knowledge and morality, we sometimes fail to see how the two sets of questions intersect. Thus, another tendency that has demarcated our understanding of education and its concomitant planning is to mistake the distinctiveness of educationally significant questions for dissociation and disconnectedness. In fact, not only have epistemological questions been pursued in isolation from questions of ethics and from other social concerns, but political operations are also often disconnected from epistemic issues. The main argument of the present article, namely, that a politicization of curiosity helps us nuance our treatment of it as an educational aim, has a bearing on the more general tendency to disconnect epistemic issues from politics because it offers a concrete example of what is lost when de-politicizations of epistemology remain unnoticed. Thus, the historical gleanings in this article that indicate political operations of curiosity may also serve as examples that illustrate (and point to the need for further research in) the politicization of epistemology. Epistemic notions are imbued with politics and cannot properly be understood in isolation from political operations.

Epistemic issues are entangled not only with moral and social issues but also with political framings; acknowledgement of the former entanglement does not take us far enough when acknowledgement of the latter entanglement is missing. This position presupposes that yet another general philosophical and educational tendency be acknowledged and interrogated. The tendency in question concerns the growing interest in social and virtue epistemologies. Typically and accurately, the emphases of social epistemology and virtue epistemology are summed up in a way that helps us notice the fact that the political is not central enough in them to come up as either a keyword or a core thesis; I borrow this summary from the Call for Papers of this Special Issue: social epistemology "employs sociological perspectives alongside traditional philosophy to explain the growth and decay of knowledge and belief systems" while virtue epistemology "sees the growth of knowledge and understanding in terms of the development of character traits." Though the tendency toward social and virtue epistemologies certainly connects the epistemic with the social and ethical in educationally beneficial ways, it is, in my opinion, open to criticisms for its failure to adequately politicize (instead of merely socializing and moralizing) epistemic notions and quandaries. I will return to this critical point in a later section precisely because the fact of a more general social- and virtue-epistemological lack of strong political awareness resonates with (or perhaps explains) the de-politicization of curiosity in education. Curiosity in virtue epistemology remains blatantly de-politicized and unreservedly promoted as an educational aim for cultivation in classrooms.

A politicization of curiosity and, more broadly, of epistemology constitutes fertile though as yet poorly mined ground both in philosophy and in education. Indeed, philosophically, curiosity is mostly treated as a virtue rather than as a mere state of mind, which is a positive development as concerns the connection of episteme with ethics, though hardly adequate for capturing political operations that justify a nuanced treatment of curiosity as an ambiguous notion.

Invested with virtue-epistemological language, the status of curiosity as an educational aim becomes enhanced. As we shall see later, the shaping of the critical thinker becomes inextricably connected with the construction of the virtuously curious learner. Virtue epistemology adds important new sensibilities to educational handlings of curiosity. Still, seeing curiosity solely as an intellectual 
virtue to be encouraged and cultivated in schools obscures the possibilities of nuanced and cautious treatments of this notion that its politicization may help us open. Awareness of political operations and investments facilitates: a qualified educational reliance on curiosity; a hermeneutically suspicious outlook on what passes as virtue or vice at a given time (and why it is important to bear such hermeneutics in mind); and a discerning approach regarding when it might be more appropriate to exercise epistemic restraint rather than epistemic curiosity.

\section{Curiosity and Education}

Early in the development of the philosophy of education into a modern discipline, H. S. Broudy posed the problem of the disconnection of knowledge acquisition from ethical life. "The gap between disinterested curiosity, which is the lifeblood of science, and the very interested concern about the uses to which the discoveries are put is difficult to ignore" [1] (p. 426, emphasis added). "The solution," according to Broudy, "lies in closing this gap, for so long as it exists there is no guarantee that the uses to which knowledge is put will not be as often evil as good" [1] (p. 426). That the disconnection of epistemic from moral issues is a problem is conveyed with the spatial metaphor of a gap: here is scientific discovery; there is its morally-charged use. Shrinking their distance is a crucial educational task. As Broudy writes: "When a problem is so serious that the only solution is the education of an entire people, then it is a serious problem indeed, for nothing is more difficult than this. Yet in a democracy we are rather committed to this extreme remedy, and, as a matter of fact, there is no more genuine remedy than this-when it works" [1] (p. 429). The key assumption, however, is that the lifeblood of science, i.e., curiosity, is disinterested (in other words, the starting point is morally and politically neutral). The problem emerges later, when discoveries are put to use.

Let us think this position through to some political-philosophical implications. The adjective "disinterested" qualifies curiosity by consolidating the assumed gap between episteme and utilization. This consolidation of the gap between curiosity and interest operates politically because it implies that science is the innocent and neutral part, and all evil that may be generated derives from the uses to which epistemic products are put and the interests that such uses may serve. By de-politicizing curiosity, the adjective "'disinterested" 'performs' in Austinian terms the political operation of exculpation of science. "Disinterested" also qualifies curiosity by policing its conceptual borders so that undesirable doubles are staved off. Left on its own, without a positive adjectival specification, curiosity is vague enough to open itself to another string of adjectives: nosy, morbid, petty, idle, and vulgar are some adjectives that add negative connotations to curiosity. By holding curiosity in check and by asserting curiosity's purportedly non-partisan character, the attribute "disinterested" that has determined the self-understanding of modern science operates politically. It does so by de-politicizing our desire to ask questions, that is, by glossing over: the power distributed through 'proper' objects of knowing; the constructed character of varying desires to know; and the 'always-already' of socio-political context that works even when the act of posing a research question is at its most spontaneous. It is ironic that the adjective "disinterested" has political effects the very moment that it asserts itself as non-political. The major political effect is that it obscures its political character in a way that facilitates its politically sanitized pretensions and blocks any political critique from being directed at it.

We may illustrate the unacknowledged political performativity of adjectival distance from undesirable doubles through David Hume's account of curiosity. Hume distinguishes three kinds of curiosity: the scientific, the nosy, and the "trembling." This last type of curiosity is religious and very interesting in its distance from the modern, inquisitive man. Trembling curiosity is a sign "of man's being still in the state of a 'barbarous, necessitous animal'." Faced with uncertainty about Nature, the 'barbarous animal' "does not engage in inquiry, but is immediately reduced to 'trembling, and sacrificing, and praying'." The contrast of "scientific" and "trembling" demarcates the political space occupied by the modern man from that occupied by "ignorant and barbarous nations" [2] (pp. 727-728). Well beyond Hume, in most modern discourses, "disinterested" curiosity, the "lifeblood" of science, has defined politicized sites, agents, and worldviews—regardless of, and before, the uses to 
which knowledge is put. In defining the curious agent and the legitimate objects of inquiry, scientific curiosity rationalized and justified in the eyes of the modern colonizers expansion and control over "non-intellectually inquisitive" natives.

Certainly, the assumption of a disinterested scientific curiosity segregated from utility, as we illustrated it through Broudy, has by now been questioned, although it has guided analytic epistemology for many years. The disunity of the epistemic and the socio-ethical that grounded Broudy's position has now given way to acknowledgement of their unity (or connection). This development has reached a point where new epistemologies are often defined through their opposition to analytic epistemology precisely on the issue of disinterestedness. Consider Steve Fuller's claim here: "my normative orientation is generally that of the interested non-participant [to me, still a de-politicization of a subject position-M.P.] in the knowledge system, which is diametrically opposed to the disinterested participant of analytic epistemology, who wishes to acquire knowledge first-hand above all else" [3] (p. xvi). Though not always responsive to political operations such as those mentioned above, social- and virtue-epistemologies have complicated disinterestedness. However, they have done so either partially or in ways that obscure rather than unveil political (rather than socio-ethical) interests.

To explain: on the one hand, social epistemologies have problematized disinterestedness by showing that a certain investment in some sense of social interest is always implicit in scientific endeavors. In Ben Kotzee's words, "social epistemology emphasises how forms of knowledge often depend on social factors for their possibility" [4] (p. 157; emphasis mine). Yet, the word "often" that I have italicized leaves open the possibility of disinterestedness as disengagement from social factors or of stepping out from participation in knowledge systems. As for the political, it does not figure in some declarative texts of social epistemology. For instance, in many chapters of the book Social Epistemology: Essential Readings [5] the political is not mentioned. In some other chapters of the book the political turns up but is either subordinated to the social or exclusively associated with democracy and Western political liberalism. When the political does turn up in other socio-epistemological texts, it is either subordinated to the social or evokes a specific political or governmental organization rather than, more generally, distributions of power and conflicting idealities concerning the future of the polis or global (instead of social) justice. Thus, politics becomes a branch of social institutions: "social epistemology holds that one may best understand how to foster the growth of knowledge by thinking about those social institutions (such as science, politics, the media or the education system) that contribute to spreading knowledge" [4] (p. 157). This reduction of the political to the social is a move that, as we know from Hannah Arendt's The Human Condition [6], was made in medieval times and deprived the political of most of its ancient critical edge. In addition, when politics is granted more independent space in social epistemology, this is done, again, in ways that privilege a specific meaning of the political. Even in Fuller's social epistemology, which is admirably more sensitive than rival versions to forms of knowledge that become vehicles of power, politics affirms a specific Western outlook of civic republicanism and constitution-making and acquires in its regulative association with epistemic justice a "negative-freedom" tone as non-domination. In his words, "from politics comes the civic republican tradition of democracy, which is founded on an ideal of liberty as non-domination. Thus, in terms of epistemic justice, the only power worth acquiring from knowledge is the power not to be dominated by others" [3] (p. xviii-xix). As I show elsewhere [7], I do not think that there is only one power worth acquiring from knowledge and certainly not just that of not being dominated by others. From knowledge we may also acquire the power to acknowledge how we have been dominating others and what pending ethico-political debts emerge from this knowledge. A better unpacking of why Fuller's connection of political ideality with non-domination does not cover the ground of a more demanding and critical politics could be done through comparisons, e.g., of Fuller's view with those of Michel Foucault (his later views on resistance to power as care of the self) or with those of Alain Badiou's conception of redemptive politics. But this cannot be carried out in this article. Suffice it then just to indicate here that Fuller's sense of politicization—see, for instance, Fuller [3] (p. 286)—is very different 
from mine and not suitable to the kind of politicization that excites Western curiosity enough to make it ask questions, e.g., about the complicity of curiosity in colonialism. In fact, to my knowledge, no such task has so far been undertaken by any researchers subscribing to social epistemology and to its politicization of knowledge.

On the other hand, virtue epistemologies have problematized disinterestedness by placing epistemic endeavors within an areteic and eudaemonist framework. Still, a dose of disinterestedness is operative when the motivation to learn is treated as inherently and naturally epistemic. This dose guarantees for the virtue-epistemologist that the distinction between intellectual and moral virtues will not collapse. Consider, for instance, Jason Baehr's following assertion: the "intellectually virtuous person is one who desires and is committed to the pursuit of goods like knowledge, truth, and understanding. It is this inherent epistemic orientation that permits a distinction between intellectual virtues and what are typically thought of as moral virtues" [8] (p. 249, emphasis mine). That the epistemic is not disinterested in the sense of being context independent but rather phronetically concretized does not entail that the acknowledged interestedness extends to awareness of political interest. Virtue epistemology complicates disinterestedness but not enough to connect epistemic interest with politics rather than exclusively with ethics. I consider this a de-politicization of Aristotelian phronesis on the part of contemporary virtue discourses, but I cannot corroborate this here, so I only state it for reasons of explaining rather than arguing my position. To illustrate my position and better explain it, let me use the example of curiosity: whereas Aristotle valued the desire for knowledge, he valorized it as wonder and not as curiosity. He did so for political reasons, i.e., because curiosity, polypragmosyne, was, to him, implicated in unjust politics [9] (p. 61). I will return to this point in the politicization section, but let me mention here that, unlike Aristotle, current virtue epistemology de-politicizes curiosity by equating it with a natural desire for knowledge (ironically, by saddling Aristotle's first lines of Metaphysics to this task) and dissociating it from political interest, thus totally overlooking Aristotle's politicization of curiosity qua polypragmosyne. Virtue epistemology glorifies curiosity as a virtue with no word about its varying political operations and, when it expresses reticence, this is only for moralist reasons when curiosity in some contexts slides into useless or gossipy interest in others. Thus, the phronetic discernment of curiosity's appropriateness cannot reach the sphere of the political because the latter is absent as a site of contestation of curiosity's significance.

The solution to the utility problem by recourse to an education that closes the gap between epistemic and ethical concerns has been widely endorsed, without, however, encouraging the kind of politicization that would have excited curiosity about curiosity's politics. Both trends in epistemology emphasize education, though differently: social epistemology still gives primacy to educational transmission of knowledge, while virtue epistemology is more oriented to the virtuous self rather than to epistemic content. From a social-epistemological point of view, Alvin Goldman writes, "the fundamental aim of education, like that of science, is the promotion of knowledge." However, he distinguishes between the two as follows: "whereas science seeks knowledge that is new for humankind, education seeks knowledge that is new for individual learners" Education pursues this mission inter alia "by organizing and transmitting pre-existing knowledge, by creating incentives and environments to encourage learning, and by shaping skills and techniques that facilitate autonomous learning" [10] (p. 349).

Virtue epistemology strengthens the mediating role of education, which is now called to cultivate not only inquisitive, scientific mindsets but also the all-round ideal of the lifelong learner. Thus, when Baehr writes of philosophy of education, he questions the adequacy of knowledge transmission. He states that "possessing even a great deal of knowledge is not sufficient"; "fostering growth in intellectual virtues [such as curiosity] should be a central educational aim" because "we can think of intellectual virtues as the personal qualities or characteristics of a lifelong learner" [8] (p. 249).

To my knowledge, social-epistemological positions, unlike virtue-epistemological ones, do not come up as frameworks of philosophical-educational discussions of curiosity. The statement in the Call for Papers of this Special Issue that curiosity "might be regarded as a virtue, and its 
development as an educational aim" correctly reflects the framework within which most of the latest educational-philosophical mentions of curiosity occur. Hence, from now on, I narrow my perspective down to virtue epistemology. I will enlarge it again only in the final section where I indicate my treatment of curiosity as an educational aim in contrast to how curiosity has been received in the field.

Some virtue-epistemological debates are important for education that sets curiosity as an aim in ways that acknowledge a sort of interestedness. For instance, is curiosity proportional to one's interest and uncertainty? If so, curiosity may be enhanced by educationally broadening one's interests and by relativizing certainties. Or, the dependence of curiosity on interest and certainty may be mitigated by another virtue, open-mindedness [11] (p. 48ff), the cultivation of which is also a cherished educational aim [8]. More generally, virtue-epistemological sensibilities chime with a "vision of a liberal arts education focused on graduating students possessing intellectual and moral virtues and not merely marketable, specialized skills" [12] (p. 403).

It is said that the chief end of all intellectual inquiry "is understanding, which is achieved through the exercise of intellectual virtue"; in practical educational terms, this requires "proposals for creating educational environments that integrate teaching for virtue" [13] (p. 82). The gap between epistemic and ethical concerns is no longer assumed because, within virtue epistemology, the former are ultimately answerable to the latter in ways that echo reformulated Aristotelian eudaimonic parlance. The epistemically virtuous person cares about intellectual goods partly because she cares "about other goods such as justice, human well-being, and friendship' [14] (p. 158). In such accounts, "love of the intellectual goods properly resides within the concern for what Aristotle calls eudaimonia-the broadest and deepest human well-being." Hence, "love of the epistemic goods is not a virtue in abstraction from other virtues" such as "justice, compassion, and a sense of civic duty" [14] (p. 158). Still, in such discourses, justice is taken in its socio-ethical sense and not in the rich ethico-political sense that it had in Aristotle (e.g., in his Politics) [6]. At any rate, the gap between the epistemic and the moral is not simply closed but rather challenged because, in Aristotle, intellectual and ethical virtues are distinguished on the grounds of how the corresponding traits are acquired [15] (p. 370), not on grounds of rigidly divided realms. Indeed, some virtues resist neat categorizations in ways that attest to intersection rather than to a gap: "many moral virtues seem to have an intellectual component, and at least some epistemic virtues an emotional one." Once again, curiosity becomes a paradigmatic case: "for example, curiosity may involve pleasure in new discovery" [15] (p. 371).

T. A. Rømer makes a point that helps us sum up the significance of virtue language for education: Aristotle is said to be interesting today "because he claims that there is a much more dialectical relationship between politics and ethics and between action and thinking." The consequences are "that one cannot study education without looking at its political environment, and that intellectual and philosophical issues return to the concept of education with full strength" [16] (p. 4).

However, in most educational discourses, when it comes to curiosity, the political environment is overlooked. Likewise, politically sensitive interrogations of what counts as curiosity and whether it should unconditionally be elevated to an educational aim are missing. The link of the relevant epistemologies and education exclusively with socialization is also telling as concerns the harnessing of the political through the social at a general level. It explains why, when epistemic approaches are narrowed down to curiosity, they involve no mention of the word "politics": "if, by educating young people, our aim is to bring them into our society in such a way that they can (eventually) cooperate with us, we have a clear interest in forming their minds in such a way that they will be good informants" [4] (p. 163). The assumption and legitimization of a social integrative interest effaces, in my view, any political-transformative and critically redirected gaze at the relation of the self with her society and with the rest of the world. If it is only "in shaping young people's intellectual capacities with social cooperation in mind" that "the interests of social epistemology, virtue epistemology and education come together" [4] (p. 163), it is no wonder that such interests have not brought politics to mind. Indeed, thorough politicizations go beyond the shaping of young people's intellectual capacities 
for social cooperation to reach moments when political contestation disrupts pseudo-consensuses and the uncritical focus on social cooperation.

Curiosity does not receive, in my view, adequately nuanced political treatment in philosophy more generally. The overall positive outlook on curiosity that we notice in post-analytic philosophy (and rival trends) is then transferred to education. Most "philosophical accounts of curiosity emphasize its epistemic achievements" [11] (p. 48). Those philosophies that treat curiosity as ambiguous incriminate the epistemic for all the negative political operations and fail to see any positive political operations in the epistemic (either as curiosity or as restraint). When they valorize curiosity they do so concerning the de-epistemicized version of it. Moreover, there are even wholly negative treatments of curiosity such as Martin Heidegger's (see, for instance, Corey McCall [17]), which also bypass any ambiguity of the notion and any nuanced politicization of it.

Especially from a virtue-epistemological point of view, stimulating curiosity becomes "central to education and learning" [18] (p. 125). This holds also when what counts as curiosity is interrogated and its educational relevance nuanced for moralist reasons (e.g., for distinguishing the scientific desire to know from the gossipy desire to pry into others' lives). Safely protected from its 'nosy' version, the "everyday sense" of curiosity becomes "uncontroversially valuable for knowledge" [18] (p. 126), as if the only problem with curiosity were the moralist one of making people open to the criticism of lacking the social skill of discretion.

\section{Politicizing Curiosity}

We now value curiosity as an epistemic virtue, and most educationists unconditionally welcome it. Yet, "unqualified praise of curiosity as an admirable character trait-as it is now often found among those writing, for example, on science and education-is a relatively recent phenomenon' [2] (p. 713). If we become curious to know more about curiosity's conceptual history and its fluctuating status in Western thought and education, we will see that both the desire to know of the 'political animal' (zoon politikon) and the theorization of this desire has inter alia been ethico-political.

Asking how the wholehearted and unreserved endorsement of curiosity as an educational aim came about could lead research on curiosity to a genealogy that sheds light on the ethico-political operations of wanting to know and of our appreciation or depreciation of wanting to know. This would help us see that ethico-political questions are inextricably connected with issues that appear at first sight (or are treated as) purely epistemological. However, an attempt to offer such a genealogy within the limits of this article would be over-ambitious, blatantly futile, or doomed to gross overgeneralizations and arbitrary leaps. Hence, what follows is an indication of how gleanings from curiosity's conceptual history may illuminate instances of its politicization. These may make us more cautious as to its educational significance, more aware of ambiguities that have remained unacknowledged and bypassed by wholehearted educational endorsements of curiosity, and more sensitive to the fact that the connection of epistemic and moral issues cannot cover the neglected ground of thinking about curiosity politically.

If we contextualize and historicize curiosity, we educators and philosophers will see that in different spatio-temporal settings (city-states, empires, and centuries), what more or less corresponded to curiosity (and its subtle semantic variations) was neither uniformly valorized nor downright incriminated. There were a variety of responses to the desire to know, and accounts of it always relied on metaphors. From antiquity to modernity, metaphors and analogies that likened curiosity to thirst and hunger or to hunting and gambling, as in Hume [2] (p. 712), offer rich material for discerning that curiosity has not been registered as an exclusively or dryly epistemic issue. Thirst and hunger naturalize and de-politicize curiosity: they have a corporeal spontaneity that gives a specific, de-politicized meaning to the natural (spontaneous and recurring physical need that manifests itself irrespective of politically differentiated access to food and drink). Curiosity is often assimilated to hunger, naturalized, and described as "appetitive and passional" even by the same thinkers who plead for its educational cultivation (with an implicit contradiction: why does something that is natural 
need cultivation instead of turning up spontaneously like hunger; why does it require constructed and contrived means to be cultivated?) And metaphorizations of curiosity through pastimes of the affluent Western nobleman (hunting, gambling) operate politically by easing Hume's passage to the assumption that the curious are those who have leisure and that the 'primitive' peoples and the low classes by necessity lack curiosity. This can be extrapolated from Hume's assertion that curiosity "requires youth, leisure, education, genius, and example to make it govern any person" [2] (p. 718) through to its political implications. The resonances of such metaphors (e.g., the curious hunter of knowledge in Hume is the adventurous, young nobleman) invite us to investigate political operations in defining curiosity and to complicate the assumption that the scope available for exploring the notion can ever be strictly or absolutely analytic.

Within the span of Greek antiquity, a variety of terms related to curiosity had been deployed. Though no easy translatability of those terms into current idioms should be assumed, this difficulty should not entail untranslatability. Instead, it points to the need for more research in the relevant contexts. Moreover, this difficulty is politically enabling because it counters a facile hijacking of ancient notions. One such hijacking is the typical reference of works on curiosity to the opening lines of Aristotle's Metaphysics, where the desire to know is considered natural (Aristotle, Meta ta Fysika,

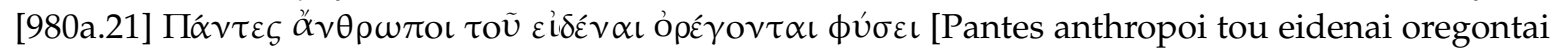
fysei]: "All people by nature desire to know"). Most approaches begin with Aristotle so as to justify their praise of curiosity as natural. However, they overlook the fact that Aristotle was not referring to curiosity. Aristotle shared with his contemporaries the view that, whilst thaymazein (wonder) was the appropriate, natural desire for knowledge [19] (p. 266), curiosity was politically undesirable [9] (p. 61). If one follows this line of thought, one will see that the early modern emphasis on the curious natural learner presupposes very different semantics of all three terms from those of the ancient equivalents back to which these terms are often traced. A side-effect of virtue-epistemological, truncated readings of Aristotle's desire to know is that they normalize and legitimize a neglect of his attitude toward polypragmosyne, which is the ancient Greek term that most closely resembles the modern notion of curiosity. (Parenthetically, another ancient variant of curiosity that more or less matches the modern notion is also overlooked: periergia. If one follows the ancient critical treatment of it, one will see that such a discussion opens up the possibility of criticizing the politics of modern speciesist 'scientific' curiosity (e.g., its needlessly and callously excessive use of animal dissection) as well as of the modern sexist and homophobic 'scientific' curiosity that was excited by the 'abnormalities' of female bodies and by naturalized understandings of homosexuality. However, such a discussion goes beyond the scope of this article.) Aristotle mistrusts polypragmosyne, echoing those philosophers and dramatists who treated it as a rationalization of Athenian expansionism [9] (p. 61). For polypragmosyne signifies a self-regarding desire to know and an active look that leads to meddling into other states' affairs. Interestingly, in Thucydides, polypragmosyne is something Athenians are proud to have but all others condemn them for, and is associated with expansion [9], giving to polypragmosyne a political, not just a moralist and socio-psychological, sense of meddling into the affairs of others. Depending on positive or negative treatments by various ancients, polypragmosyne denotes a range of senses from that of "one state's intervention into the affairs of another" to the "more commendable investigations that imperial expansion allows" [20] (p. 371). In Plato's Republic, the ethico-political frame emerges through a direct connection of justice in the ideal polis with avoidance of polypragmosyne: justice is minding one's own business and not meddling [21] (p. 480).

Thus, curiosity as one kind of epistemic desire is not, moralistically, condemned as nosiness but, politically, as predatory lust for the unknown. Though this sense of curiosity was culturally popular in Athens and contributed to the city's positive political self-image while rationalizing its expansion, it was condemned by many philosophers and poets who praised other sorts of epistemic desire [22]. Most possibly, Aristotle dislikes polypragmosyne because, as a desire for a certain kind of knowledge and control over reality, such curiosity does not hit the mean. In being closer to an epistemic akrasia, this curiosity is a vice rather than a virtue. Philosophers and poets of those centuries 
preferred apragmosyne, which "involved anti-imperialism, non-aggressive policy, quiet attitude and therefore peace" [9] (p. 52)—that is, an epistemic restraint of great political significance. Averting the eyes is valorized, opening up the space of bios theoretikos, as the apragmon retreats and takes a critical distance from immersion in sterile knowledge-hunting and un-reflective political action. Aristotle accepts this standard view "when he mentions among the people who are held in general high esteem 'the sophrones because they are not unjust, and the apragmones for the same reason' (Rhet. 1381 a, 25)" [9] (p. 61).

Therefore, against current, wholehearted, and unconditional endorsements of epistemic curiosity as a virtue andconcomitant implicit incriminations of epistemic restraint as a vice, the 5 th and 4 th century B.C. politicization of the desire for knowledge allowed for a more nuanced treatment of the terms in question. Later, in Roman times, the political, anti-imperialist note receded and curiosity was chastised from a moralist perspective, emblematic of which is Plutarch's De Curiositate/Peri Polypragmosynes.

In fact, the Latin curiositas (from cura, care) was coined to capture the meaning of polypragmosyne [21] (p. 479), as the latter had been pinned down in early Roman times. Medieval scholars, especially St. Augustine [23] (p. 242), fortified the negative associations of curiositas through religious arguments ([24], p. 81; [25], pp. 598-599; [26]). As Neil Manson writes, "in his Confessions Augustine goes on to argue that curiosity about the natural world diverts us from a proper focus on God; and that curiosity undermines, or is at odds with, faith". Manson quotes a long passage from Augustine in favor of the argument that "in The Fall, and in early Christian philosophy-Tertullian, Augustine, and Aquinas-curiosity is identified as a vice" [23] (p. 242).

Despite exceptions related to negative theology or to mysticism for which God cannot be approached cognitively, religious arguments operated politically by disparaging the interest in the natural [26] (pp. 139-141) and political world so as to promote the interest in the City of God. "Both Augustine and Aquinas made a distinction between wonder (admiratio) and curiosity (curiositas), and both conceived the latter as a vicious quest for knowledge" [12] (p. 404). To notice that things are even more complex (in ways that cannot be unpacked within the confines of this article), let us bear in mind that Aquinas valorized not only admiratio but also studiositas and distinguished it from curiositas; on this, he differed from Augustine. Many medieval authors authorized only a wonder (admiratio) at creation and an epistemic interest in the Creator as antidotes to worldly curiosity. For them, "curiositas refers to the worldly lusting of the eyes" [12] (p. 418); "this immoderate and insatiable lust to grasp cognitively creatures" is bound up with "an insatiable lust to view the new and the different" [12] (p. 419). Hence some medieval thinkers accused Aristotle of having burned with an inappropriate "desire of curiosity in understanding the causes of natural things" [19] (p. 277).

Another politicization of curiosity to glean from antiquity through to medieval and early modern employments up to now is the feminization of nosy/petty and destructive curiosity through Eve, Lot's wife, and Pandora [27] (p. 60). Such feminization should make us more careful concerning current, 'innocent' illustrations, through, say, Pandora of nosy and petty curiosity as the only undesirable desire for knowledge and unsuitable to education. A more detailed discussion of this feminization (avoided here for reasons of space) would show that, in some instances, medieval thought provided counter-examples of female figures such as Mary Magdalene, whose attitude to Christ could be described as wonder rather than curiosity. Such examples could, at least, stave off the total incrimination of the female desire for knowledge and the masculinization of the lifeblood of science that was effected later, when the only association of women with curiosity that survived the passage of curiosity from vice to virtue was the incriminated one of Pandora and Eve.

The gradual, modern transformation of curiosity from vice into virtue [28] attests to the morally and politically charged character of epistemic outlooks. On crucial issues, early modernity was marked by politically convenient passages from one outlook to another. As concerns admiratio, the positive alternative to curiositas, "wonder was no longer a prized religious emotion. Instead, it was associated with ignorance of causal explanations" [12] (p. 406). Overall, by the thirteenth century, 
"pedagogical goals changed. Natural philosophers rejected the Augustinian preoccupation with wondrous particulars," as they started favoring what they viewed as "an Aristotelian quest for scientia, complete and certain knowledge" [12] (p. 405), though, it should be noted, scientia does not cover the whole conceptual ground of Aristotle's notion of knowledge [29]). Later, in early modernity, "the wonder that had once been hailed as the philosophical passion par excellence was by 1750 the hallmark of the ignorant and barbarous. On the other hand, curiosity, for centuries reviled as a form of lust or pride, became the badge of the disinterested and dedicated naturalist" [30] (p. 304).

Whereas work was considered the punishment for the sin that caused the Fall, it was later re-imagined "to humanity's natural state and the means of overcoming the effects of the Fall" [28] (p. 677). "Thomas Hobbes, for example," who "turned his back completely on the long-standing moral tradition in his account of curiosity," "ignored the narrative of the Fall." He thus "avoided the familiar associations of pride, vanity, and forbidden knowledge. Instead, curiosity was the morally neutral appetite of knowledge'" [19] (p. 283). Likewise, innocence was "liberated from its association with ignorance in order to be considered vital for epistemological objectivity" [28] (p. 677). Hence, Hobbes's metaphor of curiosity as the "lust of the mind" is another example of the fact that epistemic terms are not dissociated from the figurative, the libidinal, the affective, etc., and, ultimately, from the political domain too, since they form part of a whole architectonic that prepared the notion of curiosity for participation in rationalizations of colonialism.

A relevant development concurs with the above: over the course of the seventeenth century the acquisition of knowledge was "gradually dissociated from the personal morality of the investigator. The first stage in the process is the shift of focus away from traditional theological virtues to civic or social virtue" [19] (p. 288). Epistemological questions were thought to be pursued in isolation from ethico-political and social questions because the legitimacy of a body of knowledge was then derived "from the following of a strict set of procedures rather than from the personal piety of the investigator" [19] (pp. 288-289). It would be an interesting line of research to explore to what extent that development marked the passage to belief-based, method-based and inquiry-process-based epistemologies. It would also be interesting to explore whether the return to the virtuous learner perspective that we experience through virtue epistemology involves a certainly more secular revival of older themes that nevertheless involves Christian morality but in a relation that is too deep to unearth through simple equations and hasty reductions.

"Curiosity rehabilitated from a vice—the cause of the original sin—to a virtue" [19] could now join travel, innocence, industriousness, and disinterested, procedural-scientific knowledge in the long list of rationalizations enabling expansion. As an "appetite for nothing other than the ownership of new knowledge," curiosity matched a conception of knowledge that demanded "seeing God's creatures not merely as new and different, but also free for the taking" [12] (p. 419). The financially profitable passage from seeing a foreign land as terra incognita to seeing it as terra nullius receptive of European industriousness was then also intellectually eased.

To sum up, from early modernity onwards, the investment of the term "curiosity" with positive scientific undertones staved off only the deprecatory implications varyingly drawn from ancient to medieval philosophy; it did not alter the spatial, semantic associations with exploring the unknown, a risky journey, heroic mobility, and edifying adventure. On the contrary, it intensified them through associations of virility, natural restlessness, industriousness and action, conquering, and learning, and an 'innocent,' though controlling and engaged, eye. Utopianizations of childhood as the site of restless natural inquisitiveness underpinned utopianizations of the curious natural learners, colonial travelers, and settlers. The curious colonial 'children' describe the terra incognita, i.e., give an account of it as well as wipe out or suppress its 'barbarity', and then inscribe on the clean slate of the (purportedly) terra nullius (empty land) the laborious products of their epistemic adventures [31].

Along with such political operationalizations of curiosity, genealogies of the concept may also reveal how the inhabitants and cultural material of the supposedly 'empty' land were filling up, as curious objects, the eyes (and spaces) of the curious European learner. The dual register of 
"'curiosity' as embodied by a physical artifact and 'curiosity' as a mental state" [32] (p. 215) provides further politicizations. Stolen or purchased artifacts filling space in burghers' homes or in curiosity cabinets, shops, museums, and central squares fulfilled European fantasies of control, power, and distinction. Human beings do not escape from the devouring eyes, as "travellers complacently recorded kidnapping natives to exhibit in England" [33] (p. 56).

The above gleanings have singled out some ancient political operations of the desire for knowledge as polypragmosyne. Some classical and Hellenistic thinkers criticized it politically and, in early Roman times, mainly morally. Translated into Latin as curiositas, the term was de-politicized and psychologized by becoming restricted to individual character. It was then socialized and moralized in medieval and pre-modern times as a harmful nosiness or irreverent interest in worldly affairs. From early modernity onwards, it was epistemicized as a prerequisite of science and associated with the utopianized, innocent, inquisitive 'child', the natural learner and adventurous traveler and the developer of unknown lands into imperial possessions. The purported disinterestedness of the lifeblood of science performed the political function of obscuring the time-honored political role of curiosity as a rationalization of colonial expansion.

Exploring curiosity politically we realize that, contra liberal assumptions of disinterestedness, not only can epistemic products be put to bad uses, but, much more, the lifeblood of science as such is imbued with interested politics, often of the worst kind. Curiosity's political-historical record shows that it was recruited to: grant primacy to the fixed over the averted gaze; turn the unknown into legitimate booty; and play a decisive role in allocations of power positions. Praised when assigned to the man of action, incriminated when assigned to women, marked as absent when associated (again) with women, low classes, and barbarous nations, curiosity demarcates who is given investigative force, who lacks curiosity due to 'natural' or cultural inferiority, and who is empowered with an active look. Apart from its theoretical role, all this was practically translated into legitimization of the death of millions, and of the destruction of non-human life and the environment for colonial and scientific purposes. From this prism, we may conclude that, against prudentialist warnings such as 'curiosity killed the cat,' some curiosity simply kills. Curiously, most such deaths still remain unknown to the postmodern learner whose education eagerly aims to cultivate curiosity, yet it has somehow failed to excite curiosity about the numbers of dead due to colonial and scientific ventures.

De-politicizing curiosity, assuming its disinterested character, and naturalizing it through the metaphor of hunger, many current discourses cultivate convenient forgetfulness. Much worse, they wittingly or unwittingly facilitate the perpetuation (even if in more disguised forms) of some of its older operations. Books written as late as 2011 still present modernity one-sidedly as a success story of European science owed to its (purportedly) privileged relation to the curiosity. As Avner Ben-Zaken writes when criticizing one such book, its aim is to "prove the absence of curiosity in non-European cultures, placing it as the prime cause for the Great Divergence between West and East" [34] (p. 586). Ben-Zaken questions what the book produces as "evidence for the lack of 'scientific curiosity' and the reason non-European civilizations fell behind." Contra such tendencies, Ben-Zaken argues that: "instead of laboring to prove the absence of curiosity and asking why no 'Galileos, Keplers, Leeuwenhoeks, or Newtons' emerged in the non-European world, it would be more beneficial to historiography to understand what actually was there in the scientific culture of the non-European" [34] (p. 587). Ben-Zaken indicates that historical complexities rather than rigid cultural demarcations led to different desires and constructions of knowledge.

A politicization of curiosity challenges modernity's success story, its disinterestedness or acknowledgement only of socio-ethical interests. It allows the voice of the 'booty' and of the 'skulls' amassed during the European triumphant march to be heard when exclaiming: "if only the Europeans in question had exercised some epistemic restraint!" 


\section{Conclusions: Interrogating Curiosity as an Educational Aim}

The praise of colonial curiosity (self-declared as "disinterested") was unqualified, unrestrained, and politically self-serving and self-exculpating, operating as rationalization of traversing, inscribing and exerting descriptive control over the other's space. Although curiosity's participation in colonialist discourse, both ancient and modern, has not been theorized enough to find a niche in postmodern discourses, other, more general complicities of episteme in violence have often led postmodernism to blanket incrimination of knowledge and of its scopic drive. Instead of adding to such an incrimination, the above indications of curiosity's political 'career' aim precisely to avoid sweeping and non-nuanced accounts that either glorify any epistemic desire or indict it wholesale. The commitment "to try to salvage a form of curiosity purged of its imperialist and masculinist tendencies" [35] (p. 450) should lead us to interrogating the unqualified welcome of curiosity (in the everyday sense of 'disinterested' curiosity [18]) as an educational aim. It should lead us to encourage epistemic restraint whenever our desire for knowledge becomes too self-regarding. On the other hand, it should also lead us to uncovering the convenient epistemic restraint that the otherwise 'curious' learner displays about politically uncomfortable knowledge when he asks too few questions and fails to direct his curiosity to thorny or 'bloody' issues. We should learn to welcome the unknown that, in becoming knowledge, shakes our certainties, up to the certainty endorsed by some thinkers that all knowledge is complicit in violence or that any educational aim to transmit knowledge should be suspect from the start. (For my handling of this possibility through the example of the Chagos unknown see Papastephanou [7]). Hence, some form of curiosity should survive the interrogation of it as an educational aim precisely because it is a curiosity directed at disclosure.

Within philosophical-educational journals, whenever curiosity comes up as an educational aim, it receives almost unconditional welcome and is never associated with political ambiguities. Even educational-philosophical treatments of curiosity that are outside virtue epistemology and derive from broadly conceived postmodern or French continental persuasions converge on the unqualified praise on curiosity (certainly for different reasons). Relying on such persuasions, pleas to turn to curiosity treat it as politically innocent and unambiguous, at least from the moment that curiosity is disconnected from its epistemic framing. Consider here the shift from knowledge to care in theorizing curiosity and the curious teacher in the following signpost of a relevant article: "from this angle we will call attention to the figure of a teacher for whom not knowledge but care is the main concern: the figure of the "caring or curious teacher'" [36] (p. 380). Obviously, the curious learner and teacher that are thus promoted are very different from those of the epistemologies that I discuss, for reasons too complex to detail here. However, what is important is that curiosity thus dissociated from epistemology and purified is considered by these philosophers/educators politically safe and unambiguous enough to be endorsed educationally with no qualifications other than the downplaying of the knowledge aspect. There is no space here for performing a full contrast of conceptions of curiosity and receptions in education along the lines of the (constructed) divide between Anglo-American and Continental philosophy and for critiquing them. However, I only mention the relevant approaches to indicate that either as an epistemic notion (through virtue epistemology) or as an ethicized notion (through Foucault's ethics of care employed by Geerinck, Masschelein and Simons, [36]) or as an aestheticized notion (through Rancière's pensive image and aesthetic acts of collage employed by Lewis, [37]), curiosity is endorsed in educational philosophy. This occurs with no attention to political ambiguities and operations. Because these operations, e.g., of colonial curiosity, are political and should become known as such, they cannot be staved off just by discarding epistemology and ethicizing or aestheticizing curiosity. Surprisingly, even philosophical-educational approaches that, due to their psychoanalytic framework, connect curiosity as an affect with a scopic drive that exerts control (such as Daniel Cho's [38]) do not politicize curiosity in ways that would produce the nuanced outlook that would make its connection with colonialism visible.

The significance of curiosity is relative to context, since it can do more harm than good if exercised in the wrong setting and circumstances. That much seems to be acknowledged and conceded in 
virtue-epistemological educational discourses (and, possibly, answered through the notion of phronetic judgment). Sometimes it is admitted that "curiosity is also subject to pathologies" and that "there are pathological states of curiosity" [18] (p. 139). Interestingly, however, all the examples that make the assertion concrete are blatantly socio-moral(ist) rather than political: "nosy, unwholesome, and morbid curiosity." For instance, had some educational thinkers not failed to politicize curiosity, they would have realized that there is more to the examples of Lot's wife, Pandora, and Ulysses-that these thinkers use to illustrate a curiosity that has been deemed morally and even epistemically pathological [18] (p. 140). They would have noticed inter alia that these examples are not equivalent and that their different theoretical handlings reveal political qua gendered treatments. This is not at all a matter of selecting examples in a politically correct way. Far from it, it is a matter of becoming aware of how those examples and the master discourses that have accompanied them have played a legitimizing role in various political complicities of the kind that the politicization of curiosity has indicated in the present article. It is also mentioned that "there are pathological forms of inquiry that reflect badly on the states or traits of curiosity that give rise to them." Consider the illustrations again: "prying, peeping, voyeurism, and rubbernecking." It is then said that "these are certainly moral but not necessarily epistemic pathologies." "Nosy, unwholesome, and morbid curiosity are epistemically objectionable only insofar as they draw us to petty knowledge, the pursuit of which distracts us from knowledge of greater importance. But not all nosy and morbid curiosity is petty" [18] (p. 139).

We may obtain a clearer picture of what virtue epistemology applied to education would consider a curiosity oriented toward petty knowledge and unsuitable to schooling through Baehr's following statement:

An intellectually virtuous person is relatively unmoved by trivial or frivolous subject matters. After all, intellectual virtues are personally admirable traits. And a love of 'junk knowledge,' for example, of the names listed in the Wichita phonebook under the letter ' $\mathrm{R}$ ' or the number of grains in a random cubic centimeter of the Sahara, is hardly admirable. [8] (p. 251)

I have argued that exhausting the challenge to epistemic curiosity discourses in moralism alone, with no awareness of political stakes makes things too easy. A possible, head-on answer to the issue of the quality of curiosity as currently theorized in most educational theory might simply be that we need "to distinguish between epistemic content (that which the agent seeks to find out) and epistemic process (the means by which she seeks to find it out)" [23] (p. 247). What the agent seeks to find out is authorized by what P. M. Opdal [39] theorizes as an accepted framework and I view, inter alia, as a political framing. The content intersects with the accepted framework in ways that make political interest constitutive of what counts as worthy knowledge at a given time and thus a more complex issue than relevant epistemologies seem prepared to acknowledge.

A critical look on Opdal's position will help me further explain my criticisms of the received view on curiosity and the significance I place onto politicizing curiosity. Opdal explores curiosity and wonder as two epistemic notions that are great educational resources. 'Curiosity is a motive that can move a person to do all kinds of research, but within an accepted framework' [39] (p. 342). That the framework is accepted entails, as I see it, that it is politically authorized and authorizing-an implication that Opdal does not draw. It is politically so because it reflects specific distributions of power, dealings with representational control over reality, specifications of legitimacy as to the proper curious agent, and normalizations of what is treated as a proper object of inquiry. In my view, not all these political operations should be welcome. They should be unveiled and contested via alternative, resisting, and liberating politics. This means that curiosity should not be encouraged unconditionally and unreflectively. Lacking political nuance, Opdal's treatment of curiosity as an educational aim ends up being uniformly positive: "as such [curiosity] will be the force behind much of what we do, within daily life, technology and science, and it should be encouraged also within education" [39] (p. 342).

Still, though Opdal does not interrogate the aim to encourage curiosity educationally, he sees that the operation of curiosity within an accepted framework risks the whole venture of cultivating a thoroughgoing quest for truth. To remedy this, he assigns to wonder the task of revisiting the accepted 
framework. Wonder "is not a motive, but an experience or state of mind signifying that something that so far has been taken for granted is incomplete or mistaken" [39] (p. 342). Thus, Opdal laments the fact that even when curiosity is advanced, this is not the case with wonder: "parents and schools do promote curiosity and curiosity-based activities"; "they bring the educational process to a halt, without continuing it by stimulating children to reflect" [39] (p. 342). The argument that I have deployed in this article entails that, when ethico-political awareness and sensibilities are missing, wonder as a challenge of what is generally taken for granted remains an abstract assumption. After all, wonder neither protected Aristotle from taking slavery for granted nor helped medieval scholars to transcend the accepted religious framework of their time when it came to vital matters. (Parenthetically, although Aristotle, a central thinker regarding the desire for knowledge as wonder, did discuss slavery in response to those of his contemporaries who challenged it, he took for granted certain assumptions of his times that naturalized slavery through accounts of the slave's body and soul as being slavish and treated all cases that did not fit in with his accepted framework as monstrous exceptions. Ironically, in my view, Aristotle, who condemned periergia (staring at something and examining it in a shallow way) based his naturalization of slavery on a periergazesthai approach (observing the slave's body) rather than on a theoretical withdrawal and distancing from conventional wisdom. However, such a deconstructive reading cannot be unpacked here and should be the subject of another article.) A heighten ethico-political awareness and commitment to critique is as necessary when wonder is the issue as it is when curiosity is the issue.

Whether labeled as curiosity or wonder, the desire for knowledge requires, in my view, an interplay with epistemic restraint based on ethico-political considerations. Curiosity and wonder may be self-regarding instead of other-regarding (e.g., the curious colonial traveler, the animal-rights-insensitive and environmentally callous scientist, etc.). In their enthusiasm to proclaim the cultivation of curiosity an educational aim, many educational thinkers neglect qualifications and preconditions and exaggerate this aim or expect too much from curiosity and its cultivation. Cultivating it alone or as a major emphasis without being aware of its politicization overlooks the fact that some virtues in isolation from other virtues may turn into vices.

However, it is not just that an intellectual virtue can turn into a vice when it is exercised in morally inappropriate situations. Epistemic virtues are tied up with political commitments of a given context in ways that complicate a uniform educational handling of virtues in isolation from one another, from related vices or in abstraction from (or in tacit, uncritical affirmation of) a spatiotemporal political framework. Awareness of some political operations of curiosity may require that we opt for epistemic restraint, a notion that never comes up in relevant educational discourses, and thus pause for thought to take a reflective distance from our everyday epistemic endeavors.

The cultivation of curiosity in schools may be conditional on the cultivation of awareness of the politicizations that underpin this character trait. It requires regulation and a mediatory intervention of political knowledge and ethical virtues. In turn, some political awareness may require the cultivation of specific intellectual virtues as well as a habituation to certain ethical virtues, e.g., as it happens when the teacher exemplifies by her own acts in the classroom a sensitivity to political aspects of issues that might at first seem apolitical.

Just as "the contents of belief are propositions, the contents of curiosity are questions" [40] (p. 5). This is important to bear in mind precisely because an interrogation of treating curiosity unconditionally as an educational aim is itself an exercise of a form of curiosity, of asking questions about why, how, and whether curiosity should be so valorized. Interrogation as a question-raising approach opposes the tendency of asking too few questions, especially when political framings are at stake. Hence the word 'interrogating' in the title of this article is neither accidental nor a capitalization on a term that is now fashionable in (broadly understood) cultural and poststructuralist discourses. As a questioning of questioning, it entails that we should be curious about our displayed curiosity and our unconscious epistemic restraints. In other words, it urges us to ask questions about our questions, 
about our failing to ask questions and about our failure to epistemically restrain ourselves whenever such restraint is needed.

Conflicts of Interest: The author declares no conflict of interest.

\section{References}

1. Broudy, H.S. Disinterested Curiosity and Social Concern. J. High. Educ. 1943, 14, 426-430. [CrossRef]

2. Gelfert, A. Hume on Curiosity. Br. J. Hist. Philos. 2013, 21, 711-732. [CrossRef]

3. Fuller, S. Social Epistemology; Indiana University Press: Bloomington, IL; Indianapolis, IN, USA, 2002.

4. Kotzee, B. Introduction: Education, Social Epistemology and Virtue Epistemology. J. Philos. Educ. 2013, 47, 157-167. [CrossRef]

5. Goldman, A., Whitcomb, D., Eds.; Social Epistemology: Essential Readings; Oxford University Press: Oxford, UK, 2011.

6. Arendt, H. The Human Condition; University of Chicago Press: Chicago, IL, USA, 1989.

7. Papastephanou, M. Virtue-Epistemology and the Chagos Unknown: Questioning the Indictment of Knowledge Transmission. Ethics Educ. 2015, 10. forthcoming.

8. Baehr, J. Educating for Intellectual Virtues: From Theory to Practice. J. Philos. Educ. 2013, 47, 248-262. [CrossRef]

9. Ehrenberg, V. Polypragmosyne: A Study in Greek Politics. JHS 1947, 67, 46-67. [CrossRef]

10. Goldman, A. Knowledge in a Social World; Oxford University Press: Oxford, UK, 1999.

11. Far, A. Explicating Curiosity via Uncertainty and Interest, Augmented with Open-Mindedness. J. Gen. Philos. 2015, 1, 48-54.

12. Merrick, T. Teaching Philosophy: Instilling Pious Wonder or Vicious Curiosity? Chr. Sch. Rev. 2010, 39, 401-420.

13. Ortwein, M. The Regulation of Understanding through Intellectual Virtue. J. Thought 2015, 71-85. Available online: http://journalofthought.com/wp-content/uploads/2015/07/08ortwein.pdf (accessed on 15 September 2015). [CrossRef]

14. Roberts, R.; Wood, J. Intellectual Virtues: An Essay in Regulative Epistemology; Clarendon Press: Oxford, UK, 2007.

15. Driver, J. The Conflation of Moral and Epistemic Virtue. Metaphilosophy 2003, 34, 367-383. [CrossRef]

16. Rømer, T.A. Thought and Action in Education. Educ. Philos. Theor. 2013, 260-275. [CrossRef]

17. McCall, C. Some Philosophical Ambiguities of Curiosity in the Work of Heidegger, Foucault, and Gadamer. J. Br. Soc. Phenomenol. 2011, 42, 176-193. [CrossRef]

18. Schmitt, F.; Lahroodi, R. The Epistemic Value of Curiosity. Educ. Theor. 2008, 58, 125-148. [CrossRef]

19. Harrison, P. Curiosity, Forbidden Knowledge, and the Reformation of Natural Philosophy in Early Modern England. Isis 2001, 92, 265-290. [CrossRef] [PubMed]

20. Morrison, G. Classical Curiosity. Classical Rev. 2014, 64, 369-371. [CrossRef]

21. DeFilippo, J.G. Curiositas and the Platonism of Apuleius' Golden Ass. Am. J. Philol. 1990, 111, 471-492. [CrossRef]

22. Leigh, M. From Polypragmon to Curiosus: Ancient Concepts of Curious and Meddlesome Behaviour; Oxford University Press: Oxford, UK, 2013.

23. Manson, N.C. Epistemic Restraint and the Vice of Curiosity. Philosophy 2012, 87, 239-259. [CrossRef]

24. Walsh, P.G. The Rights and Wrongs of Curiosity (Plutarch to Augustine). Greece Rome 1988, 35, 73-85. [CrossRef]

25. Peters, E. The Desire to Know the Secrets of the World. J. Hist. Ideas 2001, 62, 593-610. [CrossRef]

26. Kołos, A. Imagining Otherness: The Pleasure of Curiosity in the Middle Ages. Mirabilia 2014, 18, 118-150.

27. Mulvey, L. Fetishism and Curiosity; Indiana University Press: Bloomington, IL; Indianapolis, IN, USA, 1996.

28. Aldridge, L. From Vice to Virtue: Curiosity and work in early modern England. Metascience 2012, 21, 677-678. [CrossRef]

29. Eikeland, O. The Ways of Aristotle; Peter Lang: Bern, Switzerland, 2008.

30. Daston, L.; Park, K. Wonders and the Order of Nature; Zone: New York, NY, USA, 1998.

31. Papastephanou, M.; Gregoriou, Z. Locke's Children? Rousseau and the Beans (Beings?) of the Colonial Learner. Stud. Philos. Educ. 2014, 33, 463-480. [CrossRef] 
32. Carroll, K.Z. Curating Curiosity: Wonder's Colonial Phenomenology'. In Frameworks, Artworks, Place: The Space of Perception in the Modern World; Rodopi: Amsterdam, The Netherlands, 2008; pp. 203-225.

33. Skura, M.A. Discourse and the Individual: The Case of Colonialism in "The Tempest". Shakespeare Q. 1989, 40, 42-69. [CrossRef]

34. Ben-Zaken, B.A. Review of Toby Huff's book Intellectual Curiosity and the Scientific Revolution: A Global Perspective. Br. J. Hist. Sci. 2011, 44, 585-587. [CrossRef]

35. Phillips, R. The Impact Agenda and Geographies of Curiosity. Trans. Inst. Br. Geogr. 2010, 35, 447-452. [CrossRef]

36. Geerinck, I.; Masschelein, J.; Simons, M. Teaching and Knowledge: A Necessary Combination? An Elaboration of Forms of Teachers' Reflexivity. Stud. Philos. Educ. 2010, 29, 379-393. [CrossRef]

37. Lewis, T.E. Teaching with Pensive Images: Rethinking Curiosity in Paulo Freire's Pedagogy of the Oppressed. J. Aesthetic Educ. 2012, 46, 27-45. [CrossRef]

38. Cho, D.K. Curiosity according to Psychoanalysis: Blumenberg, Freud, and the Destiny of an Affect. New Ger. Critiq. 2008, 35, 191-205. [CrossRef]

39. Opdal, P.M. Curiosity, Wonder and Education seen as Perspective Development. Stud. Philos. Educ. 2001, 20, 331-344. [CrossRef]

40. Whitcomb, D. Curiosity was Framed. Philos. Phenomenol. Res. 2010, 81, 664-687. [CrossRef]

(C) 2015 by the author; licensee MDPI, Basel, Switzerland. This article is an open access article distributed under the terms and conditions of the Creative Commons by Attribution (CC-BY) license (http:/ / creativecommons.org/licenses/by/4.0/). 